\title{
The Izaña BSRN station
}

\section{La estación BSRN de Izaña}

\author{
R. D. García(1,2), R. $\operatorname{Ramos}^{(1)}$, E. Cuevas(1), V. E. Cachorro(2,S), A. M. de $\operatorname{Frutos}^{(2, S)}$ \\ 1. Izaña Atmospheric Research Center, Meteorological State Agency of Spain, AEMET, Spain. \\ 2. Atmospheric Optics Group. Valladolid University (GOA-UVA), Spain. \\ ${ }^{(*}$ Email: rgarciac@aemet.es \\ S: miembro de SEDOPTICA / SEDOPTICA member \\ Recibido / Received: 30/01/2011. Aceptado / Accepted: 30/08/2011.
}

\begin{abstract}
:
The BSRN (Baseline Surface Radiation Network) is a project of the Radiation Panel from the Global Energy and Water Cycle Experiment (GEWEX) under the umbrella of the World Climate Research Programme (WCRP). Since March 2009 the Izaña Atmospheric Observatory belongs to the BSRN network. The Izaña Observatory is a Global Atmospheric Watch station. It is a high mountain station, located at Tenerife Island (2.367 m. above sea level). The measurements recorded in this station are sent on a monthly basic to the BSRN database are: global, direct, diffuse, longwave downward, net, UV-A, UV-B radiation and the data obtained with rawinsondes launched daily from the Santa Cruz de Tenerife station, located $30 \mathrm{~km}$ from the Izaña station. In this work we focused on the study of the global, direct and diffuse radiation measurements, performed at the Izaña Observatory during 2009. The results show a high quality of BSRN measurements. Although Izaña is a high mountain station there are 357 days with valid measurements for 2009. A 99\% of the measurements are within the limits recommended by the BSRN. Furthermore there is a very good agreement between the measurements and the simulated values with the radiative transfer model LibRadtran using a sample set of 129 days with cloud free sky conditions. The daily values of the global and direct radiation show a RMSE lower than $2 \%$, while the diffuse radiation shows a RMSE of about $10 \%$.
\end{abstract}

Keywords: BSRN, Izaña, Global Radiation, Direct Radiation, Diffuse Radiation, LibRadtran Model.

\section{RESUMEN:}

La BSRN (Baseline Surface Radiation Network) es un proyecto del Observatorio de Radiación perteneciente al Global Energy and Water Cycle Experiment (GEWEX) en el marco del Programa Mundial de Investigaciones Climáticas (WRCP). Desde Marzo de 2009 el Observatorio Atmosférico de Izaña pertenece a la red BSRN. El Observatorio de Izaña forma parte de la red de estaciones de Vigilancia Atmosférica Mundial (VAG-GAW). Es una estación de alta montaña, situada en la Isla de Tenerife a 2.367 m.s.n.m. En esta estación las medidas que se envían mensualmente a la BSRN son: radiación global, directa, difusa, radiación de onda larga descendente, radiación neta, UV-A, UV-B así como los datos obtenidos de los sondeos que diariamente se realizan en la estación de Santa Cruz de Tenerife, situada a $30 \mathrm{~km}$ de la estación de Izaña. En este trabajo nos hemos centrado en el estudio de las medidas de radiación global, directa y difusa tomadas en el Observatorio de Izaña durante el año 2009. Los resultados muestran la buena calidad que presentan las medidas, ya que a pesar de ser una estación de alta montaña, existen numerosos días con medidas válidas, en concreto 357 días en el año 2009. La gran mayoría de las medidas, más del 99\%, cumplen los límites recomendados por la red BSRN. Además existe un excelente acuerdo entre las medidas experimentales y los valores obtenidos con el modelo de transferencia radiativa LibRadtran para una muestra de 129 días sin nubes. Los valores diarios de la radiación global y directa presentan un RMSE menor del 2\%, mientras que para la difusa el RMSE es de aproximadamente el $10 \%$.

Palabras clave: BSRN, Izaña, Radiación Global, Radiación Directa, Radiación Difusa, Modelo LibRadtran 


\section{REFERENCIAS Y ENLACES / REFERENCES AND LINKS}

[1]. http://www.awi.bsrn.de

[2]. A. Ohmura, E. G. Dutton, B. Forgan. C. Fröhlich, H. Gilgen, H. Hegner, A. Heimo, G. König-Langlo, B. McArthur, G.Müller, R. Philipona, R. Pinker, C. H. Whitlock, K. Dehne, M. Wild, "Baseline surface radiation network (BSRN/WCRP): New precision radiometry for climate research", Bull. Am. Meteorol. Soc. 79, 2115-2136 (1998).

[3]. L. J. B. McArthur, Baseline Surface Radiation Network (BSRN), Operations Manual. WMO/TD-No. 879, WCRP/WMO (2004).

[4]. http://www.aemet.izana.org

[5]. H. Hegner, G. Müller, V. Nespor, A. Ohmura, R. Steigrad, H. Gilgen, "Update of the technical plan for BSRN data management”, WMO/TD-No.882, WCRP/WMO (1998).

[6]. http://www.ndsc.ncep.noaa.gov/

[7]. C. N Long, E. G Dutton, "BSRN global network recommended QC tests", V2.0, BSRN Technical Report (2002).

[8]. http://www.libradtran.org/

[9]. R. D.García, V. E.Cachorro, E. Cuevas, A. Redondas, A. M.de Frutos, A. Berjón, "Comparison of measured and modelled UV spectral irradiance at the Izaña station based on LibRadtran and UVAGOA models", Opt. Pura Apl. 45, 11-15 (2012).

[10]. http://www.pangaea.de/

\section{Introduction}

The primary reason for the joint scientific committee of the World Climate Research Programme (WCRP) to establish in 1988 the international Baseline Surface Radiation Network (BSRN) was the importance of precise and accurate radiation measurements for climate research.

Within the global atmospheric monitoring program of the WMO (World Meteorological Organization), the University of Valladolid and the Meteorological State Agency of Spain (AEMET-IARC) signed a specific agreement of collaboration for the establishment of methodologies and quality assurance systems for photometry, radiometry, atmospheric ozone and aerosols programs. One of the objectives of this agreement is the development of methodologies and applications necessary to establish a BSRN station (Baseline Surface Radiation Network) at the Izaña Atmospheric Observatory.

\section{BSRN - Baseline Surface Radiation Network}

The BSRN is a project of the Radiation Panel from the Global Energy and Water Cycle
Experiment (GEWEX) under the umbrella of the World Climate Research Programme (WRCP). In 2004 the BSRN was designated as the global baseline network for surface radiation for the Global Atmospheric Watch (GAW). At present, more than 50 stations in contrasting climatic zones (Fig. 1), covering a latitude range from $80^{\circ} \mathrm{N}$ to $90^{\circ} \mathrm{S}$, are providing data to the BSRN local archive at the Alfred Wegener Institute (AWI) in Bremerhaven, Germany. The network objective is to provide observations of the best possible quality, for shortwave and longwave surface radiation fluxes, with high temporal resolution (one to three minutes). These measurements are taken from a small number of selected stations, in different climatic zones, together with upper air meteorological data and other observations. The measurements of the BSRN network are used for: 1) monitoring the background shortwave and longwave radiative components and their changes with the best methods currently available; 2) providing data for the validation and evaluation of satellitebased estimates of the surface radiative fluxes and 3) producing high-quality observational data for comparison to climate model calculations and for the development of local regionally representative radiation climatologies $[2,3]$. 


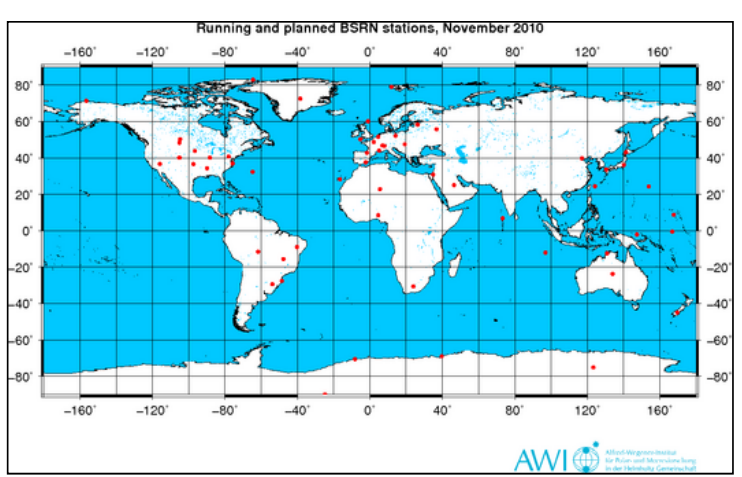

Fig. 1. Map of BSRN stations by November 2010.

\section{Izaña Observatory}

The Izaña Atmospheric Observatory (IZA) is a Global Atmospheric Watch (GAW) station located in Tenerife Island (Canary Islands) at $28^{\circ} 18^{\prime} \mathrm{N}, 16^{\circ} 29^{\prime} \mathrm{W}, 2367 \mathrm{~m}$ above sea level.

Tenerife is a volcanic island about $300 \mathrm{~km}$ from the African continent and about $1400 \mathrm{~km}$ from the Iberian Peninsula. The Izaña Observatory is characterized by a clean and pristine air. It is located in the region below the descending branch of the Hadley cell, typically above a stable inversion layer. IZA is located on an island, above a quasi-permanent inversion layer, far away from any significant industrial activities. Consequently it offers excellent conditions for "in-situ" measurements of trace gases and aerosols under "free troposphere" conditions and for atmospheric observations by remote sensing techniques. The environmental conditions (stable total column ozone, very low column water vapour and low aerosols content) and the high frequency of clean and pristine skies make IZA to be optimal for calibration and validation activities. Due to its geographic location it is in particular valuable for the investigation of dust transport from Africa to the North Atlantic, and of upper troposphere-lower stratosphere long range transport from the tropics to the pole [4].

\section{Instruments and measurements of Izaña BSRN}

Since March 2009 the Izaña Atmospheric Observatory belongs to the BSRN network. The measurements of the BSRN Izaña are divided into three main categories: "basic", "expanded" and "other measurements" [1,5].

The "basic measurements" at the Izaña station are diffuse solar irradiance, direct sky irradiance, longwave downward irradiance, and global irradiance. The "expanded measurement" at the Izaña are aerosol optical depth (Cimel Photometer and Precision Filter Radiometer PFR), total ozone content (Brewer Spectroradiometer) and the vertical distribution of pressure, air temperature, dew point, relative humidity, wind speed and wind direction obtained with ozone soundings. The Brewer and the ozonesonde programs are part of the NDACC program [7]. Finally the "other measurements" at the station are short and longwave upward irradiance, UVA solar irradiance and UVB solar irradiance. Figure 2 shows some of the BSRN related instruments installed at the IZA BSRN.

The data acquisition system used is a Campbell CR-5000. The system records measurements at the rate of up to 5000 samples/second with 16-bit resolution.

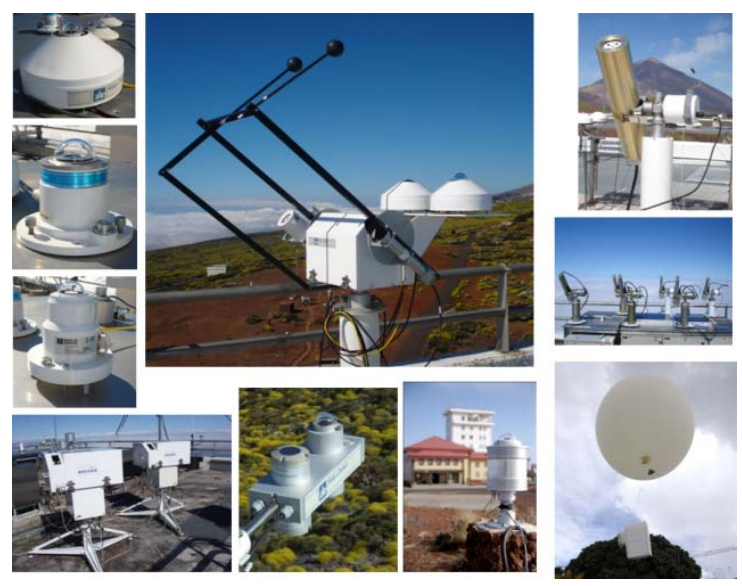

Fig 2. Instruments installed at the IZA BSRN.

\section{Validation and quality control}

During the year 2009 the database was designed in order to manage the large volume of BSRN data. This tool not only allows the management of the large volume of information generated in an orderly and systematic manner, but it is also used for real-time checking of all measurements becoming compressive a quality control system with corresponding alarms. 
The data flow from measurements to the BSRN Database is shown in Fig. 2. First, the measurements acquired by a Campbell CR-5000 acquisition system are stored on a computer on a daily basis (PC Data Acquisition). These measurements pass an automated quality control. If it is passed, data is sent to the database where is stored. On the contrary, the "flagged" measurements are manually revised. The database serves as a tool to write the file is submitted to the BSRN on a monthly basis [1]. The measurements received by the BSRN are analyzed to verify that data fulfill the requirements. The quality control is based on "physical possible limits", "extremely rare limits" and comparison with model computations. The BSRN established the limits for surface irradiance measurements [7]. The comparison with the model is obtained with LibRadtran model [8] using as input observed parameters. The two most important parameters to introduce into the model in the solar range are aerosol optical depth and total column water vapour. Another important parameter is the atmosphere profile. In this work, the vertical profiles for ozone, pressure and temperature are taken from the soundings performed at Santa Cruz de Tenerife station during the 1992-2007 period.
The measurements passed the quality control are incorporated into the WRMC (World Radiation Monitoring Center) and redistributed via ftp and the web based Publishing Network for Geoscientific \& Environmental Data "Pangea" [10].

During 2010 a web-database tool has been developed to obtain IZA-BSRN real-time measurements and facilitate the near real time checking of all instruments. This tool also allows the consultation of stored measurements into the database.

\section{Results}

In 2009 the Izaña BSRN station recorded 357 valid days of measurements. Five days were eliminated because adverse weather conditions, while there were three days in which the absence of data was due to instruments maintenance. That indicates that, despite the high mountain location of the station, the daily maintenance and control of instruments allowed to obtain a $97.8 \%$ of days with valid measurements.

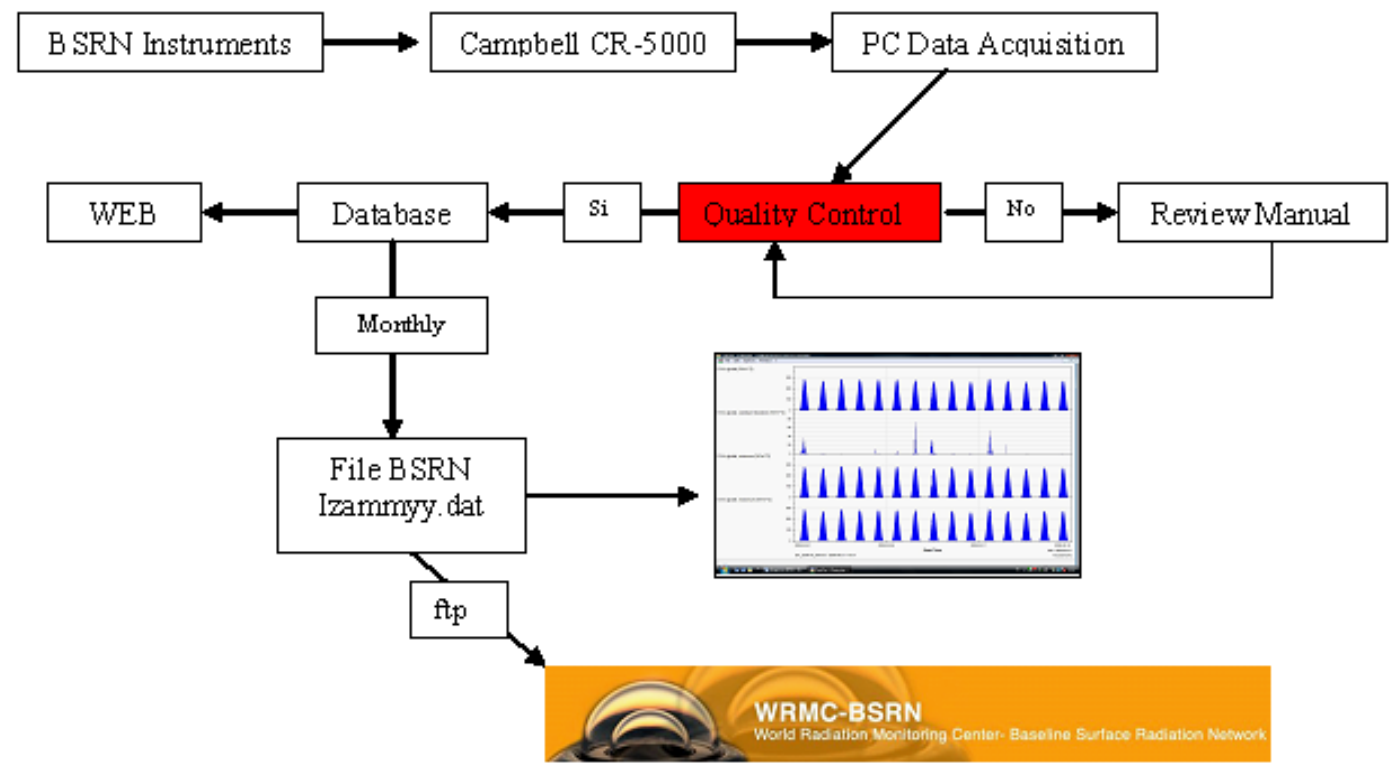

Fig 3. Flow data from measurements to the BSRN database.. 
We present the results obtained by applying the testing physically possible limits and globally extremely rare limits as defined and used in the BSRN recommended data quality control (QC) [7]. Table I is a summary of the percent of data that satisfied the quality control tests for the three main radiation components: global, direct and diffuse shortwave radiation.

As we can see on Table I, the whole dataset satisfied the physically possible limits, except the diffuse component, which presents a $0.06 \%$ of data higher the maximum limits. All the data satisfied the minimum physically possible limits.

Concerning the extremely rare limits, we find a little fraction of data higher than the maximum extremely rare limits for each component, with $0.03 \%$ wrong data for global radiation, $0.01 \%$ for the direct radiation and $0.63 \%$ for the diffuse. The minimum extremely rare limits are fulfilled by all data.

The last quality control is done by comparing the observation against model simulation. We have selected cloud-free sky conditions at the IZA during 2009 and compared with the daily value of the performed global, direct and diffuse irradiances, and the corresponding simulations obtained with the radiative transfer model LibRadtran $[8,9]$.

The global and direct components show a good agreement with a R2 and slope very close to 1 , and a small RMSE, lower than $1.8 \%$. The diffuse component shows a poorer fit. The R2 is 0.988 , the slope 0.991 and the RMSE higher than $10 \%$. The positive sign of the MBE indicates an overestimation, as it happens with the global and direct radiation. The value of the MBE for the global radiation is very close to zero. The diffuse radiation is underestimated as indicated by the negative sign for the MBE. These results lead us to trust on the model to be used as a quality control system for the observation.
Table I

Percent of data passed QC testing in 2009 at Izaña station.

\begin{tabular}{|c|c|c|c|c|}
\hline \hline \multicolumn{2}{|c|}{} & $\begin{array}{c}\text { Global } \\
\text { SW (\%) }\end{array}$ & $\begin{array}{c}\text { Direct SW } \\
\text { (\%) }\end{array}$ & $\begin{array}{c}\text { Diffuse } \\
\text { SW (\%) }\end{array}$ \\
\hline $\begin{array}{c}\text { Physically } \\
\text { Possible }\end{array}$ & Max. & 100 & 100 & 99.94 \\
\cline { 2 - 5 } & Min. & 100 & 100 & 100 \\
\hline $\begin{array}{c}\text { Extremely } \\
\text { Rare }\end{array}$ & Max. & 99.97 & 99.99 & 99.37 \\
\cline { 2 - 5 } & Min. & 100 & 100 & 100 \\
\hline
\end{tabular}

\section{Tables II-III}

Statistics of the agreement between model simulation and observed daily values during 2009 at IZA BSRN for cloudfree sky conditions.

\begin{tabular}{|c|c|c|c|c|}
\hline \hline & $\begin{array}{c}\text { Number } \\
\text { of days }\end{array}$ & Slope & $\begin{array}{c}\text { Y } \\
\text { Intercept }\end{array}$ & $\mathbf{R}^{\mathbf{2}}$ \\
\hline Global & 129 & 1.022 & -44.994 & 0.999 \\
\hline Direct & 129 & 0.987 & 110.002 & 0.996 \\
\hline Diffuse & 129 & 0.991 & -16.993 & 0.988 \\
\hline
\end{tabular}

\begin{tabular}{|c|c|c|c|}
\hline \hline & RMSE(\%) & MBE(\%) & MABE(\%) \\
\hline Global & 1.159 & 0.653 & 0.966 \\
\hline Direct & 1.781 & 1.361 & 1.515 \\
\hline Diffuse & 10.222 & -6.711 & 8.905 \\
\hline
\end{tabular}

The slope of the regression, correlation coefficients $\left(\mathrm{R}^{2}\right)$, Root Mean Square Error (RMSE), Mean Bias Error (MBE), Mean Absolute Bias Error (MABE).

\section{Acknowledgements.}

This work was developed within the Specific Agreement of Collaboration between the University of Valladolid and the CIAI-AEMET entitled "Establishment of methodologies and quality assurance systems for photometry, radiometry, atmospheric ozone and aerosols programs within the WMO-GAW". Financial supports from the Spanish MICIIN (ref. CGL2008-05939-CO3-00/CLI and CGL2009 09740) and from the GR-220 Project of the Junta de Castilla y León are Gratefully acknowledged. 